\title{
Description of OAE and BERA Click Examination Result at Adam Malik General Hospital in 2017-2019
}

\author{
Tommy A. Rifaldy*, HR Yusa Herwanto*, Delfitri Munir* \\ * Department of Otorhinolaryngology-Head and Neck Surgery, \\ Faculty of Medicine, Universitas Sumatera Utara-Haji Adam Malik General Hospital, Medan, Indonesia \\ DOI: 10.29322/IJSRP.11.12.2021.p12042 \\ http://dx.doi.org/10.29322/IJSRP.11.12.2021.p12042
}

\begin{abstract}
Objective: This study aims to describe the results of OAE and BERA click examinations at Haji Adam Malik General Hospital Medan during 2017 - 2019 based on the age, gender, birth weight, gestational age, and type of delivery. Method: This study is a retrospective descriptive study with secondary data. The sample includes 84 people, assembled by non-probability sampling technique with consecutive sampling. Result: The majority of OAE results of the right ear was patients aged 1-3 years (40.6\%), male (53.6\%), low birth weight $(47.8 \%)$, very premature status $(40.6 \%)$, and history of spontaneous delivery $(76,8 \%)$. While majority of the left ear was patients aged 1-3 years (40.3\%), male (46.8\%), low birth weight $(51.6 \%)$, very premature statues $(40.3 \%)$, and history of spontaneous delivery $(72,6 \%)$. On the BERA click examination, the majority of patients were aged 1 - 3 years old with $\mathrm{V}$ wave (-) $(60.7 \%)$ and $\mathrm{V}$ wave (+) (26.8\%). Males with V wave (+) (53.6\%) and V wave (-) (53.6\%). Low Birth Weight with V wave (-) (71.4\%) and $\mathrm{V}$ wave $(+)(30.4 \%)$, moderate to late infants with $\mathrm{V}$ wave $(-)(53.6 \%)$ and $\mathrm{V}$ wave $(+)(16.1 \%)$. History of spontaneous labor with $\mathrm{V}$ wave (-) (82.1\%) and V wave (+) (71.4\%). Conclusion: The OAE and BERA click examinations can be used as screening methods for early detection of hearing loss in infants bearing risk factors.
\end{abstract}

Keywords : Hearing loss, OAE, BERA click

\section{INTRODUCTION}

Hearing loss in children is very common, globally it is estimated that as many as 5 out of 1000 newborns suffered from hearing loss. Hearing loss was thought to be the leading cause of disability worldwide. In 2019, it is estimated that around 466 millions people in the world have hearing loss, of which 34 millions are children. The majority of people with hearing loss reside in middle to low income countries. Around 180 million deaf individuals come from Southeast Asia. ${ }^{1}$

Based on the results of the Riset Kesehatan Dasar (Riskesdas) conducted by the Health Research and Development Agency (Balitbangkes) of the Ministry of Health in 2018, the proportion of hearing loss in children aged 24-59 months in Indonesia is $0.1 \% .2$

The incidence of hearing loss was 7 times higher in the very preterm infant group, 2 times in the moderately premature infant and 1.5 times in the late premature infant. Low birth weight, gestational age, low Apgar score, administration of antibiotics at 1 week postpartum and neonatal seizures are associated with risk of hearing loss. Severe hypoxia is known to cause permanent injury to the outer hair cells and vascular stria in the cochlea, causing hearing loss. 3

The Infant Hearing Screening (IHS) program has been implemented and developed in order to identify hearing loss in children as early as possible. The IHS program has developed early behavioral observation techniques and screening method based on physiological measurements such as Oto-Acoustic Emission (OAE) and Brainstem Response Evoke Audiometry (BERA). ${ }^{4}$
OAE examination is the most frequently used test as a screening due to the procedure being easy, safe, and fast. This test is also easy to interpret and sensitive to the presence of hearing loss. OAE also does not require special skills. If the results of OAE indicates hearing loss, or the results are "refer", then the neonate must undergo BERA examination before the age of 3 months. The BERA examination is sufficiently good and economical in neonates screening, as well as to further identify the degree and type of hearing loss in children. ${ }^{5}$

This study aims to assess the distribution of hearing loss in children based on OAE and BERA Click values at H. Adam Malik General Hospital Medan in 2017 - 2019.

\section{METHOD}

This study is a retrospective descriptive design performed by documenting secondary data from the medical records of patients who underwent hearing screening at the ENT outpatient clinic Haji Adam Malik General Hospital, Medan. The study sample was patients who underwent OAE and BERA click examinations at Haji Adam Malik General Hospital Medan in 2017 - 2019 with a total of 84 patients. The sampling technique in this study was a non-probability sampling technique with consecutive sampling. The inclusion criteria is in the form of all patients with complete medical records in accordance with all examined research variables. Patients who did not meet the inclusion criteria in this study were not included in the study sample.

\section{RESULT}


ISSN 2250-3153

Based on 2017 - 2019 data on 84 children who underwent right ear OAE examination at $\mathrm{H}$. Adam Malik General Hospital Medan, it was found that the majority of patients were children aged 1-3 years old $(40.6 \%)$, male gender $(53.6 \%)$, low birth weight $(47.8 \%)$, very premature gestational age $(40.6 \%)$, and a history of spontaneous delivery $(76.8 \%)$. While in the left ear, the majority of patients were children aged 1-3 years old $(40.3 \%)$, male gender $(46.8 \%)$, low birth weight $(51.6 \%)$, very premature gestational age $(40,3 \%)$, and having a history of spontaneous delivery $(72.6 \%)$ had an OAE refer result, which indicates a hearing loss.

Furthermore, BERA click examination was performed and it was found that the majority of patients aged 1-3 years with the results of $\mathrm{V}$ wave (-) $60.7 \%$ and $\mathrm{V}$ wave (+) $26.8 \%$. Male gender with the results of $\mathrm{V}$ wave (+) $53.6 \%$ and $\mathrm{V}$ wave (-) $53.6 \%$. Low birth weight with the results of $\mathrm{V}$ wave (-) $71.4 \%$ and $\mathrm{V}$ wave (+) $30.4 \%$, moderate to late gestational age with results in $\mathrm{V}$ wave (-) $53.6 \%$ and $\mathrm{V}$ wave (+) $16.1 \%$. History of spontaneous labor with the results of $\mathrm{V}$ wave (-) was $82.1 \%$ and $\mathrm{V}$ wave (+) was $71.4 \%$.

\section{DISCUSSION}

Hearing loss in children covers a wide pathological range. Early detection and appropriate treatment are crucial to support the normal development of language and psychosocial function of children, as well as to identify potentially reversible causal or other causes of hearing loss.6

In this study, it was found that the majority of OAE examination results with refer were children aged 1-3 years, as many as 28 children $(40.6 \%)$ in the right ear and 25 children $(40.3 \%)$ in the left ear. This is due to the awareness of parents who just found out about speech delays when the children aged 1-3 years, thus hearing loss can only be detected at this age. These results are in accordance with the research of Nguyen et al, who found that the majority of OAE refer results were in children aged $<3$ years $(30 \%) .7,8$

The majority of male children had a refer result of 37 children $(53.6 \%)$ in the right ear and 29 children $(46.8 \%)$ in the left ear. These results are in accordance with the study of Nguyen et al, they found that the majority of OAE refer results were in boys $(56 \%) .8$

Infants born with low birth weight often have problems with delayed neurological and sensory development. Cakranegara \& Widuri found that OAE refer results mostly occur in infants with low birth weight (40\%). This shows that low birth weight is a significant risk factor for hearing loss. 9,10

In this study, it was found that children with low body weight status had OAE refer results as many as 33 children $(47.8 \%)$ in the right ear, and 32 children (51.6\%) in the left ear.

It was found that 15 children $(26.8 \%)$ aged $1-3$ years had $\mathrm{V}$ wave (+) results and 17 children $(60.7 \%)$ had $\mathrm{V}$ wave results (-

Table 1. Results distribution of OAE and BERA click on research variables

\begin{tabular}{ccccccc}
\hline Variable & \multicolumn{2}{c}{ Right Ear OAE } & \multicolumn{2}{c}{ Left ear OAE } & \multicolumn{2}{c}{ BERA click } \\
& Pass & Refer & Pass & Refer & Gel V(+) & Gel V (-) \\
\hline Age & & & & & & \\
< 1 year & $4(26.7 \%)$ & $22(31.9 \%)$ & $7(31.8 \%)$ & $19(30.6 \%)$ & $26(46.4 \%)$ & $0(0.00 \%)$ \\
1-3 years & $4(26.7 \%)$ & $28(40.6 \%)$ & $7(31.8 \%)$ & $25(40.3 \%)$ & $15(26.8 \%)$ & $17(60.7 \%)$ \\
$>$ 3 - 5 years & $6(40.0 \%)$ & $11(15.9 \%)$ & $6(27.3 \%)$ & $11(17.7 \%)$ & $10(17.9 \%)$ & $7(25.0 \%)$
\end{tabular}

This publication is licensed under Creative Commons Attribution CC BY.
).This result is in line with a study conducted by Thirunavukarasu, et al who performed BERA examination in children and high-risk infants under 10 years. $68 \%$ of patients belonged to the age group $1-5$ years. ${ }^{11}$

In this study, 15 male patients (53.6\%) had BERA results with $\mathrm{V}$ wave (-), this is in accordance with research from Osama et al, who showed that hearing loss was more common in boys than girls. $^{12}$

The incidence of hearing loss is higher in infants with lower birth weight or shorter maternal gestational age. The longer the gestational age of the mother or the weight gain of the baby, the chance of hearing loss was decreased. This study revealed 20 children (71.4\%) with the results of $\mathrm{V}$ wave (-) having low birth weight and $\mathrm{V}$ wave (+) with low birth weight found in 17 children $(30.4 \%){ }^{13}$

Premature infants often have brain lesions, small brain stem volume, insufficient white matter, inferior colliculus disorders and abnormalities in the migration and myelination processes. In this study, the majority of children with $\mathrm{V}$ wave (-) results were $15(53.6 \%)$ and they were children with moderate to late gestational age and $9(32.1 \%)$ were very premature infants. ${ }^{14}$

It was found that 40 children (71.4\%) who had a $\mathrm{V}$ wave (-) were born spontaneously, while 23 children $(82 \%)$ had a V wave (+) result. The results of the study by Kepekci in 2019 stated that there was no relationship between the type of spontaneous delivery and cesarean section on the results of the BERA examination $(\mathrm{p}=0.61){ }^{151}$

\section{CONCLUSION}

The OAE and BERA click examinations can be used as screening methods for early detection of hearing loss in infants with risk factors, such as low birth weight, gestational age, and type of delivery. 


\begin{tabular}{cllllll}
$>5$ years & $1(6.7 \%)$ & $8(11.6 \%)$ & $2(9.1 \%)$ & $7(11.3 \%)$ & $5(8.9 \%)$ & $4(14.3 \%)$ \\
Total & $15(100 \%)$ & $69(100 \%)$ & $22(100 \%)$ & $62(100 \%)$ & $56(100 \%)$ & $28(100 \%)$ \\
\hline $\begin{array}{c}\text { Gender } \\
\text { Male }\end{array}$ & $8(53.3 \%)$ & $37(53.6 \%)$ & $16(72.7 \%)$ & $29(46.8 \%)$ & $30(53.6 \%)$ & $15(53.6 \%)$ \\
Female & $7(46.7 \%$ & $32(46.4 \%$ & $6(27.3 \%)$ & $33(53.2 \%)$ & $26(46.4 \%)$ & $13(46.4 \%)$ \\
Total & $15(100 \%)$ & $69(100 \%)$ & $22(100 \%)$ & $62(100 \%)$ & $56(100 \%)$ & $28(100 \%)$
\end{tabular}

\section{Birth Weight}

$\begin{array}{cllllll}\text { Normal } & 10(66.7 \%) & 24(34.8 \%) & 15(68.2 \%) & 19(30.6 \%) & 29(51.8 \%) & 5(17.9 \%) \\ \text { Low } & 4(26.7 \%) & 33(47.8 \%) & 5(22.7 \%) & 32(51.6 \%) & 17(30.4 \%) & 20(71.4 \%) \\ \text { Very low } & 1(6.7 \%) & 12(17.4 \%) & 2(9.1 \%) & 11(17.7 \%) & 10(17.9 \%) & 3(10.7 \%) \\ \text { Total } & 15(100 \%) & 69(100 \%) & 22(100 \%) & 62(100 \%) & 56(100 \%) & 28(100 \%)\end{array}$

\section{Gestational Age}

$\begin{array}{cllllll}\text { Mature } & 10(66.7 \%) & 19(27.5 \%) & 13(59.1 \%) & 16(25.8 \%) & 25(44.6 \%) & 4(14.3 \%) \\ \text { Moderate to late } & 2(13.3 \%) & 22(31.9 \%) & 3(13.6 \%) & 21(33.9 \%) & 9(16.1 \%) & 15(53.6 \%) \\ \text { Very premature } & 3(20 \%) & 28(40.6 \%) & 6(27.3 \%) & 25(40.3 \%) & 22(39.3 \%) & 9(32.1 \%) \\ \quad \text { Total } & 15(100 \%) & 69(100 \%) & 22(100 \%) & 62(100 \%) & 56(100 \%) & 28(100 \%)\end{array}$

\begin{tabular}{cllllll}
\hline Type of Delivery & & & & & & \\
Spontaneous & $10(66.7 \%)$ & $53(76.8 \%)$ & $18(81.8 \%)$ & $45(72.6 \%)$ & $40(71.4 \%)$ & $23(82.1 \%)$ \\
Cesarian Section & $5(33.3 \%)$ & $16(22.2 \%)$ & $4(18.2 \%)$ & $17(27.4 \%)$ & $16(28.6 \%)$ & $5(17.9 \%)$ \\
Total & $15(100 \%)$ & $69(100 \%)$ & $22(100 \%)$ & $62(100 \%)$ & $56(100 \%)$ & $28(100 \%)$
\end{tabular}

\section{REFERENCES}

1.WHO.INT (2020, 1 Maret). Deafness and hearing loss. Diakses pada 1 November 2020 dari https://www.who.int/news-room/factsheets/detail/deafness-and-hearing-loss

2. Pusdatin. 2019. Infodatin Disabilitas Rungu. Jakarta: Pusat Data dan Informasi Kementerian dan Kesehatan RI.

3. Hirvonen M, et al. Visual and Hearing Impairments After Preterm Birth. Pediatrics 2018; 142: e20173888

4. Bhatt, J., \& Chhangte, L. 2015. Accuracy of OAE and BERA to Detect the Incidence of Hearing Loss in Newborn. International Journal of Scientific and Research Publications, 1-6

5. Lawrensia S, Gomez Pomar E. Newborn Hearing Screening. [Updated 2020 Aug 1]. In: StatPearls. Treasure Island (FL): StatPearls Publishing; 2020 Jan.

6. Dimitrov L, Gossman WG. Pediatric Hearing Loss. [Updated 2020 Jul 21]. In: StatPearls. Treasure Island (FL): StatPearls Publishing; 2020 Jan-.

7. Thakkar D, Barot D. Brainstem-evoked response audiometry in pediatric age group. Indian J Otol 2018; 24: 246-51.

8. Nguyen TX, Accuracy of Otoacustic Emission in Comparison to Diagnostic Test of Auditory Brainstem Response in Hearing Screening for Children in Vietnam. Sys Rev Pharm 2020; 11(5): 469-471

9. Norton, SJ \& Perkins, JA. 2005. Early detection and diagnosis of infant hearing impairment, dalam CW Cummings, PW Flint, BH Haughey, KT Robbins, JR Thomas, LA Harker \& MA Richardson (eds), Otolaryngology: head \& neck surgery, Mosby, Inc, Philadelphia.

10. Cakranegara LA, Widuri A. 2014. Hearing Impairment in Newborn with Risk Factor Low Birth Weight in PKU Muhammadiyah Yogyakarta Hospital.

11. Thirunavukarasu R, Balasubramaniam GK, Kalyanasundaram RB, Narendran G, Sridhar S. A study of brainstem evoked response audiometry in highrisk infants and children under 10 years of age. Indian J Otol 2015; 2: 134-7.

12. Osama H, Tamer S, Wael S. Prevalence and pattern of hearing loss in children in house- held National surveys in Egypt. EJENTAS. 2010; 11:12-6.

This publication is licensed under Creative Commons Attribution CC BY. http://dx.doi.org/10.29322/IJSRP.11.12.2021.p12042
13. Baron, IS, \& Rey-Casserly, C. 2010. Extremely preterm birth outcome: A Review of Four Decades of Cognitive Research, Neuropsychol Rev, vol 20, hal 430452

14. Reiman, M, Riitta Parkkola, R, Johansson, R, Jääskeläinen, SK, Kujar, H \& Lehtonen, L, Haataja, L \& Lapinleimu, H. 2009. Diffusion tensor imaging of the inferior colliculus and brainstem auditory-evoked potentials in preterm infants, Pediatr Radiol, vol. 39, hal.8049.

15. Kepekçi AH. 2018. Section 2: Sub-Fields in Audiometry. Audiometry: Hearing and Measurement Vestibular System, Neurotology: Nobel Medical Bookstores pp. 105-124.

\section{AUTHORS}

First Author - Tommy A. Rifaldy, Faculty of Medicine, Universitas Sumatera Utara-Haji Adam Malik General Hospital,Medan, Indonesia, tar6686@ gmail.com

Second Author - HR Yusa Herwanto, Universitas Sumatera Utara-Haji Adam Malik General Hospital,Medan, Indonesia, herwantoyusa67@gmail.com

Third Author - Delfitri Munir Universitas Sumatera UtaraHaji Adam Malik General Hospital,Medan, Indonesia, delfitrimunirs3@gmail.com 